\title{
PENGARUH GAYA BELAJAR TERHADAP KEMAMPUAN PENALARAN MATEMATIS SISWA
}

\section{The Influence Of Learning Style On Student's Mathematical Reasoning Ability}

\author{
Sitti Sumaeni ${ }^{1)}$ Kodirun $^{1)}$, Salim $^{1)^{*}}$ \\ ${ }^{1}$ Jurusan Pendidikan Matematika, Universitas Halu Oleo, Jl. H.E.A. Mokodompit Kampus Hijau Bumi \\ Tridharma Anduonohu Kota Kendari 93231, Indonesia. \\ *)E-mail korespondensi: salimpsa@gmail.com
}

\begin{abstract}
The purpose of this research is (1) to describe the learning style of class VII students in SMP Negeri 10 Kendari; (2) to describe the mathematical reasoning ability of class VII students in SMP Negeri 10 Kendari; (3) to learn the influence of learning style to mathematical reasoning ability of class VII students in SMP Negeri 10 Kendari. This research is an expost-facto study. The sampling technique used proportional random sampling, with 65\% of the number of students in each parallel class of 132 students. The results of this study showed that (1) learning styles of class VII students in SMP Negeri 10 Kendari were $46.21 \%$ visual learning style, $28.03 \%$ auditory learning style, and $25.76 \%$ kinaesthetic learning style; (2) mathematical reasoning ability of class VII students in SMP Negeri 10 Kendari was in very high category at $1.51 \%$, high category at $13.63 \%$, average category at $18.93 \%$, fair category at $65.90 \%$ and none poor category; (3) learning styles had significant influence on mathematical reasoning ability of the students.
\end{abstract}

Keywords: auditorial learning style, kinaesthetic learning style, mathematical reasoning, visual learning style.

\begin{abstract}
ABSTRAK
Tujuan penelitan ini yaitu (1) untuk mendeskripsikan gaya belajar pada siswa kelas VII di SMP Negeri 10 Kendari; (2) untuk mendeskripsikan kemampuan penalaran matematis siswa kelas VII di SMP Negeri 10 Kendari; (3) untuk mengetahui adanya pengaruh gaya belajar terhadap kemampuan penalaran matematis siswa di kelas VII SMP Negeri 10 Kendari. Penelitian ini merupakan penelitian expost-facto. Teknik pengambilan sampel menggunakan proportional random sampling, yaitu 65\% dari jumlah siswa pada masing-masing kelas paralel sebanyak 132 siswa. Hasil penelitian ini menunjukkan bahwa (1) gaya belajar siswa kelas VII SMP Negeri 10 Kendari yaitu gaya belajar visual sebesar 46,21\%, gaya belajar auditorial sebesar 28,03\%, dan gaya belajar kinestetik sebesar 25,76\%.; (2) kemampuan penalaran matematis siswa kelas VII di SMP Negeri 10 Kendari yaitu berkategori sangat tinggi sebesar 1,51\%, berkategori tinggi sebesar 13,63\%, berkategori sedang sebesar 18,93\%, berkategori kurang sebesar 65,90\% dan berkategori sangat kurang tidak ada ; (3) gaya belajar mempunyai pengaruh yang signifikan terhadap kemampuan penalaran matematis siswa
\end{abstract}

Kata kunci: gaya belajar auditorial, gaya belajar visual, gaya belajar kinestetik, penalaran matematis.

\section{PENDAHULUAN}

Matematika menjadi pelajaran yang dianggap sulit bagi sebagian besar siswa. Kesulitan belajar disebabkan oleh faktor siswa yang tidak mengerti dengan baik isi materi dari pelajaran matematika (Hasibuan, 2018). Ketidakmampuan siswa dalam memahami matematika karena kesulitan mengaitkan antara pengetahuan baru dengan pengetahuan sebelumnnya (Waskitoningtyas, 2016). Dalam belajar matematika diperlukan beberapa kemampuan yang harus dikuasai siswa agar mudah memahami konsep matematika. Menurut Effendi dalam Alifin, Kodirun, \& Ikman (2018) kemampuan matematis yang harus dikuasai siswa melalui pembelajaran matematika, yaitu : (1) koneksi (connection); (2) penalaran dan pembuktian (reasoning and proof); (3) komunikasi (communication); (4) pemecahan masalah (problem solving); serta (5) representasi (representation). Menurut Nurhayati \& subekti (2017) kemampuan penalaran merupakan bagian penting dan kunci dari pembelajaran matematika. Afif, Suyitno, \& Wardono (2017) juga berpendapat bahwa bila kemampuan penalaran tidak ditambahkan dan tidak dikembangkan kepada siswa, maka bagi siswa matematika hanya akan menjadi materi yang mengikuti serangkaian prosedur dan meniru contohcontoh tanpa mengetahui maknanya. Dalam ruang lingkup matematika, kemampuan menalar siswa merupakan salah satu hal penting karena sebelum siswa menentukan langkah yang akan dilaksanakan 
diharapkan mampu memahami dengan cara menalar soal tersebut dengan cermat dan detail sehingga soal dapat diselesaikan dengan cepat

Seseorang memiliki kemampuan untuk memahami dan menyerap pelajaran berbeda-beda caranya yakni ada yang cepat, sedang dan ada pula yang sangat lambat (Ridwan, 2017). Hal ini tergantung dengan kecenderungan dan kebiasaan gaya belajar siswa yang berbeda-beda pula. Drumond mengungkapkan "an individual's preferred mode and desired condition of learning". Maksudnya, gaya belajar dianggap sebagai cara belajar atau kondisi belajar yang disukai oleh pembelajar (Syarfuni \& Verawati, 2017). Kolb, Honey, \& Mumford dalam (Jafre et.al, 2011) menggambarkan gaya belajar sebagai cara yang disukai atau kebiasaan individu dalam mengolah dan mentransformasi pengetahuan. Begitu pula Dunn \& Dunn dalam (Pashler et.al, 2009) menjelaskan bahwa gaya belajar adalah cara dimana setiap siswa mulai berkonsentrasi, memroses, menyerap, dan mempertahankan informasi baru. Jadi, gaya belajar adalah cara yang cenderung dipilih siswa untuk bereaksi dan menggunakan perangsang-perangsang dalam menyerap dan kemudian mengatur serta mengolah informasi pada proses belajar. DePorter dan Hernacki dalam (Hamidah, 2016) menyatakan bahwa gaya belajar merupakan kombinasi dari cara seseorang menyerap, mengatur, serta mengolah informasi.

Afiatman, Samparadja, \& Anggo (2019) mengungkapkan gaya belajar dibagi menjadi tiga yaitu gaya belajar visual, gaya belajar auditori dan gaya belajar kinestetik. Menurut Zariah, Kodirun \& Masi (2019) tipe gaya belajar visual merupakan gaya belajar yang lebih banyak memanfaatkan penglihatan. Orang dengan gaya belajar visual akan melihat atau membayangkan apa yang sedang dibicarakan. Selain itu, ia memiliki kepekaan yang kuat terhadap warna. Hanya saja ia memiliki kendala untuk berdialog secara langsung karena terlalu reaktif terhadap suara, sehingga sulit mengikuti anjuran secara lisan dan sering salah menginterprestasikan kata atau ucapan. Tipe kedua yaitu gaya belajar auditori adalah gaya belajar yang memanfaatkan indera pendengaran untuk mempermudah proses belajar. Tipe ketiga adalah gaya belajar kinestetik yaitu gaya belajar yang lebih mudah menyerap informasi dengan bergerak, berbuat, dan menyentuh sesuatu yang memberikan informasi tertentu agar ia bisa mengingatnya. Ketika seseorang mengetahui gaya belajar yang dimiliki, orang tersebut akan mengetahui apa yang menjadi kelebihan dan kekurangannya. Oleh karena itu, setiap gaya belajar harus dibedakan demi memaksimalkan trik belajar yang ada pada setiap gaya belajar.

Berdasakan hasil observasi yang dilakukan dikelas VII di SMPN 10 Kendari, ditemukan berbagai permasalahan yang muncul terkait pembelajaran matematika yaitu saat guru menyampaikan materi pembelajaran, hanya beberapa orang siswa yang memperhatikan dan mendengarkan. Siswa juga kurang aktif dalam proses pembelajaran, dimana para siswa belum berani mengungkapkan jawaban dari pertanyaan yang diberikan oleh guru. Tidak hanya itu, siswa tidak paham dalam mempelajari konsep dasar matematika sehingga siswa belum mampu memberikan pilihan lain dalam berbagai argument jawaban dan siswa menganggap pelajaran matematika adalah pelajaran yang sulit.

Setiap siswa memiliki kemampuan yang berbeda-beda dalam menerima dan memproses suatu informasi. Hal ini mengakibatkan siswa juga menempuh cara yang berbeda untuk menerima informasi tersebut. Salah satunya adalah adanya perbedaan gaya belajar yang dimiliki siswa. Artinya ketika guru melakukan proses pembelajaran dengan metode ceramah di depan kelas, tanya jawab, dan mengerjakan latihan dalam hal ini akan menguntungkan siswa yang mempunyai gaya belajar auditorial, padahal tidak semua siswa mempunyai gaya belajar auditorial tersebut. Situasi ini tentu kurang mempertimbangkan aspek kecenderungan siswa yang bervariasi gaya belajarnya.

Berdasarkan informasi yang diperoleh dari salah seorang guru matematika kelas VII di SMP Negeri 10 Kendari, siswa kesulitan dalam memahami permasalahan yang diberikan terutama dalam menuliskan jawaban secara sistematis. Guru juga menyatakan bahwa kemampuan yang paling sulit untuk dikembangkan adalah kemampuan penalaran karena dalam proses pembelajaran siswa mengalami kesulitan dalam memberikan dugaan terhadap soal yang berbeda. Banyak diantara siswa yang masih bingung dalam menjawab permasalahan tersebut. Hal ini menyebabkan guru memberikan permasalahan yang sama dengan contoh soal sebelumnya yang berbeda hanya dari segi angka yang digunakan. 
Dari hasil observasi dan wawancara di atas dapat ditarik kesimpulan bahwa kesulitan-kesulitan dalam mempelajari matematika diakibatkan oleh siswa tidak memahami konsep matematika sehingga siswa kurang menyukai pelajaran matematika tersebut. Hal ini menyebabkan kemampuan penalaran matematis siswa menjadi tidak berkembang. Sementara itu kemampuan penalaran matematis adalah salah satu standar kemampuan matematika yang sangat penting untuk dipelajari dan dikembangkan.

Penalaran merupakan salah satu kompetensi dasar dalam matematika disamping pemahaman, komunikasi dan pemecahan masalah. Asdi dalam Linola, Marsitin, \& Wulandari (2017) memberikan definisi penalaran sebagai proses dari budi manusia yang berusaha tiba pada suatu keterangan baru dari sesuatu atau beberapa keterangan lain yang telah diketahui dan keterangan yang baru itu mestilah merupakan urutan kelanjutan dari sesuatu atau beberapa keterangan yang semula itu. Suriasumantri dalam (Fauzan \& Fahinu, 2016) menyatakan bahwa penalaran merupakan suatu proses berpikir dalam menarik simpulan yang berupa pengetahuan. Berpikir diartikan oleh Soemanto dalam (Hamidah, 2016) sebagai peletakan hubungan antar bagian pengetahuan seperti konsep, informasi, gagasan, dan pengetahuan yang telah dimiliki atau diperoleh manusia untuk membentuk suatu pengertian, pendapat, atau keputusan.

Kemampuan penalaran setiap individu berjenjang berdasarkan tingkat perkembangan individu tersebut. Penalaran (reasoning) merupakan suatu konsep umum yang menunjuk pada salah satu proses berpikir untuk sampai pada suatu kesimpulan sebagai pernyataan baru dari beberapa pernyataan lain yang telah diketahui. Kesimpulan yang bersifat umum dapat ditarik dari kasus-kasus yang bersifat individual. Tetapi dapat pula sebaliknya, dari hal yang bersifat individual menjadi kasus yang bersifat umum. Bernalar adalah melakukan percobaan di dalam pikiran dengan hasil dari setiap langkah dalam untaian percobaan tersebut telah diketahui oleh penalar (Jamilun \& Suhar, 2016).

Penalaran merupakan suatu kegiatan, proses, suatu aktivitas berpikir untuk menarik kesimpulan atau membuat suatu pernyataan baru yang benar dan berdasarkan pada pernyataan yang kebenarannya sudah dibuktikan atau sudah diasumsikan sebelumnya. Pentingnya kemampuan penalaran matematis tercantum dalam tujuan pembelajaran matematika yaitu agar siswa memiliki kemampuan menggunakan penalaran pada pola dan sifat, melakukan manipulasi matematis dalam membuat generalisasi, menyusun bukti atau menjelaskan gagasan dan pernyataan matematika (Nisa \& Ismail, 2018). Meskipun penalaran matematis merupakan aspek penting, tetapi masih banyak siswa lemah dalam penalaran matematis. Menurut Shadiq dalam Adianto, Sudia \& Misu (2016) indikator penalaran yang harus dicapai oleh siswa antara lain: (a) kemampuan menyajikan pernyataan matematika secara lisan, tertulis, gambar dan diagram, (b) kemampuan melakukan manipulasi matematika, (c) menarik kesimpulan, menyusun bukti, memberikan alasan atau bukti terhadap kebenaran solusi, (d) kemampuan memeriksa keshahihan suatu argument, (e) kemampuan menarik kesimpulan dari pernyataan, (f) menemukan pola atau sifat dari gejala matematis untuk membuat generalisasi.

Kurangnya kemampuan penalaran matematis siswa dipengaruhi oleh beberapa faktor seperti gaya belajar, kecemasan matematika instruksi, kurangnya rasa percaya diri, kepercayaan guru, lingkungan, kurangnya perhatian orangtua, serta jenis kelamin (Afif, Suyitno, \& Wardono, 2017). Kemampuan siswa dapat dikembangkan dengan maksimal apabila guru mengetahui gaya belajar setiap siswanya. Dunn \& Dunn dalam Syukur \& Misu (2016) mengemukakan bahwa membuat siswa menyadari gaya belajar mereka dan membantu mereka mengembangkan kemampuan belajar yang sesuai dengan gaya belajar mereka memiliki efek yang positif terhadap hasil nilai akademik atau hasil belajar siswa. Siswa-siswa yang belajar dari pendekatan atau teknik mengajar yang sesuai dengan gaya belajar mereka cenderung akan menghasilkan nilai akademik yang lebih tinggi dan memiliki sikap yang lebih baik terhadap proses pembelajaran.

Penelitian terkait gaya belajar dan penalaran matematis siswa dilakukan oleh Sari \& Sufri (2014) bahwa siswa dengan gaya auditori memiliki kesalahan berupa kesalahan konseptual dan kesalahan prosedural. Haryono \& Tanujaya (2018) dalam penelitiannya mengungkapkan penalaran induktif matematika mahasiswa dengan gaya belajar visual lebih baik dari gaya belajar auditori dan kinestetik. Penelitian ini berbeda dengan kedua penelitian tersebut yang lebih berfokus pengaruh gaya belajar baik secara keseluruhan maupun parsial terhadap kemampuan penalaran matematis 
siswa. Hasil dari penelitian ini memberikan kontribusi bagi guru untuk menetapkan strategi belajar yang cocok dengan aneka variasi gaya belajar yang dimiliki siswa sehingga pencapaian kemampuan penalaran matematis siswa dapat meningkat secara lebih baik. Mengingat akan pentingnya gaya belajar dan kemampuan penalaran siswa dalam rangka meningkatkan kualitas belajar siswa maka diperlukan kajian pada pengaruh gaya belajar terhadap kemampuan penalaran matematis siswa SMP Negeri 10 Kendari. Tujuan penelitan ini yaitu (1) untuk mendeskripsikan gaya belajar pada siswa kelas VII di SMP Negeri 10 Kendari; (2) untuk mendeskripsikan kemampuan penalaran matematis siswa kelas VII di SMP Negeri 10 Kendari; (3) untuk mengetahui adanya pengaruh gaya belajar terhadap kemampuan penalaran matematis siswa di kelas VII SMP Negeri 10 Kendari.

\section{METODE}

Jenis penelitian yang digunakan adalah ex post facto. Pada penelitian ini tidak mengadakan kegiatan pembelajaran karena kegiatan pembelajaran telah dilakukan oleh guru bidang studi matematika yang mengajar di sekolah tersebut. Populasi dalam penelitian ini adalah seluruh siswa kelas VII SMP Negeri 10 Kendari yang terdaftar pada tahun ajaran 2019/2020 sebanyak 203 orang. Teknik pengambilan sampel dilakukan secara proportional random sampling sebanyak $65 \%$ tiap-tiap kelas. Dengan mengambil 65\% tiap-tiap kelas tersebut, maka jumlah sampel dalam penelitian ini adalah 132 orang siswa.

Instrumen yang digunakan dalam penelitian ini yaitu angket gaya belajar dan tes kemampuan penalaran matematis. Gaya belajar terdiri dari tiga yaitu gaya belajar visual dengan indikator: (a) memahami sesuatu dengan asosiasi visual, (b) rapi dan teratur, (c) mengerti dengan baik mengenai posisi, bentuk, angka dan warna, (d) sulit menerima instruksi verbal. Gaya belajar auditori dengan indikator: (a) belajar dengan cara mendengarkan, (b) lemah terhadap aktivitas visual, (c) memiliki kepekaan terhadap musik, (d) baik dalam aktivitas lisan. Gaya belajar kinestetik dengan indikator: (a) belajar melalui aktivitas fisik, (b) selalu berorientasi pada fisik dan banyak bergerak, (c) peka tehadap ekspresi dan bahasa tubuh, (d) menyukai kegiatan coba-coba. Sedangkan tes kemampuan penalaran disusun berdasarkan enam jenis masalah penalaran matematis, yaitu : (a) menyajikan pernyataan matematika secara lisan, tertulis, gambar dan diagram, (b) melakukan manipulasi matematika, (c) menarik kesimpulan, menyusun bukti, memberikan alasan atau bukti terhadap kebenaran solusi, (d) memeriksa keshahihan suatu argumen, (e) menarik kesimpulan dari pernyataan, (e) menemukan pola atau sifat dari gejala matematis untuk membuat generalisasi.

Analisis data dalam penelitian ini ada dua macam, yaitu analisi deskriptif dan analisis inferensial. Analisis statistik deskriptif diperlukan untuk mendeskripsikan atau menggambarkan karakteristik distribusi masing-masing data variabel (gaya belajar dan kemampuan penalaran matematis siswa) berupa mean, median, modus, nilai minimum, nilai maksimum, dan standar deviasi. Untuk gaya belajar menggunakan kriteria berikut.

Tabel 1. Pengkategorian Gaya Belajar Siswa

\begin{tabular}{lcl}
\hline No & Interval & \multicolumn{1}{c}{ Kategori } \\
\hline 1 & $X>\bar{X}+1,5 S D$ & Sangat Tinggi \\
\hline 2 & $\bar{X}+0,5 S D<X \leq \bar{X}+1,5 S D$ & Tinggi \\
\hline 3 & $\bar{X}-0,5 S D<X \leq \bar{X}+0,5 S D$ & Sedang \\
\hline 4 & $\bar{X}-1,5 S D<X \leq \bar{X}-0,5 S D$ & Rendah \\
\hline 5 & $X \leq \bar{X}-1,5 S D$ & Sangat Rendah \\
\hline
\end{tabular}

Kriteria kemampuan penalaran matematis siswa tersaji pada Tabel 2.

Tabel 2. Kriteria Tingkat Kemampuan Penalaran Matematis

\begin{tabular}{lcl}
\hline No. & Interval & \multicolumn{1}{c}{ Kriteria } \\
\hline 1 & $86-100$ & Sangat Tinggi \\
\hline 2 & $76-85$ & Tinggi \\
\hline 3 & $66-75$ & Sedang \\
\hline 4 & $\leq 65$ & Rendah \\
\hline 5 & $0-15$ & Sangat Rendah \\
\hline
\end{tabular}


Tahap selanjutnya dalam analisis data adalah analisis inferensial. Melalui analisis inferensial kita dapat mengetahui apakah hipotesis dalam penelitian ini diterima atau ditolak. Dalam analisis inferensial, terdapat beberapa tahap analisis yang menjadi prasyarat untuk melakukan analisis uji hipotesis yaitu analisis uji normalitas data dan analisis uji linearitas data. Setelah melalui syarat uji normalitas dan uji linearitas maka dilanjutkan dengan uji hipotesis. Pada pengujian hipotesis menggunakan teknik analisis regresi linear sederhana. Analisis ini digunakan untuk menjelaskan pengaruh gaya belajar $(\mathrm{X})$ terhadap kemampuan penalaran $(\mathrm{Y})$, dengan model persamaan regresi linear sederhana adalah sebagai berikut: $\mathrm{Y}=\beta_{0}+\beta_{1} \mathrm{X}_{\mathrm{i}}+\varepsilon$ untuk $(\mathrm{i}=\mathrm{I}, \ldots)$

Pengujian hipotesis dalam analisis regresi linear sederhana digunakan statistik uji $t$ dengan menggunakan SPSS. Pengambilan keputusan dapat dilakukan dengan membandingkan nilai signifikansi yang terdapat pada output SPSS dengan $\alpha=0,05$, dengan kriteria : tolak $\mathrm{H}_{0}$, jika nilai signifikansi lebih kecil dari $\alpha=0,05$ dan diterima $\mathrm{H}_{0}$, jika nilai signifikansi lebih besar dari $\alpha=0,05$.

Untuk mengetahui seberapa pengaruh yang diberikan oleh gaya belajar terhadap kemampuan penalaran matematis siswa kelas VII SMP Negeri 10 Kendari digunakan koefisien determinasi dengan menggunakan alat bantu SPSS. Rumus yang digunakan untuk menghitung nilai koefisien determinasi adalah: $\mathrm{D}=r^{2} \times 100 \%$

\section{HASIL DAN PEMBAHASAN}

Gaya belajar adalah cara yang dipakai oleh seseorang dalam proses menerima dan memahami sebuah ilmu pengetahuan. Menurut Gunawan dalam Nurhayati \& Subekti (2017) gaya belajar merupakan cara yang lebih disukai dalam melakukan kegiatan berpikir, memproses dan mengerti suatu informasi. Tidak semua siswa memiliki gaya belajar yang sama, di mana setiap siswa memiliki gaya belajar yang alami dan nyaman bagi mereka masing-masing. Sebagian siswa lebih suka bila guru mereka mengajar dengan menuliskan segalanya dipapan tulis, sehingga mereka dapat membaca dan memahaminya. Tetapi sebagian siswa lain lebih suka bila guru menyampaikan materi secara lisan sehingga mereka dapat mendengarkan dan memahami. Ada juga siswa yang lebih suka membentuk kelompok kecil dan mendiskusikan materi pelajaran. Selain itu, ada juga siswa yang lebih suka dengan pembelajaran menggunakan alat peraga. Semua cara yang dipakai siswa dalam proses belajar dapat disimpulkan sebagai gaya belajar. Namun, terkadang para siswa bahkan tidak menyadari gaya belajarnya sendiri sehingga tidak dapat menggunakannya secara efektif dalam proses belajar. Menurut Barbe dan Swassing dalam (Sari, 2014) gaya belajar individu dapat dibagi dalam 3 (tiga) kategori. Ketiga kategori tersebut adalah gaya belajar visual, auditorial dan kinestetik. Berikut ini disajikan tabel distribusi siswa berdasarkan gaya belajar siswa kelas VII SMP Negeri 10 Kendari.

Tabel 3. Distribusi Jumlah Siswa Berdasarkan Gaya Belajar

\begin{tabular}{|c|c|c|}
\hline Gaya Belajar & Jumlah Siswa & Persentase (\%) \\
\hline Visual & 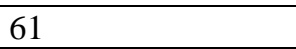 & 46,21 \\
\hline Auditorial & 37 & 28,03 \\
\hline Kinestetik & 34 & 25,76 \\
\hline Jumlah & 132 & 100 \\
\hline
\end{tabular}

Hasil pada Tabel 3 menunjukkan bahwa siswa kelas VII SMP Negeri 10 Kendari mayoritas memiliki gaya belajar visual. Sisanya sebagian siswa meliki gaya belajar auditorial dan gaya belajar kinestetik dnegan sebaran persentase yang cukup sama.

Hasil gaya belajar siswa kelas VII SMP Negeri 10 Kendari menandakan setiap siswa memiliki gaya belajar masing-masing. Oleh karena itu, guru yang memegang peranan penting haruslah cerdas dalam mengelola teknik mengajarnya, menyesuaikan dengan variasi gaya belajar siswa dalam kelas. Hal ini sejalan dengan yang dikemukakan oleh Felder \& Henriques dalam (Nurhayati \& Subekti, 2017) bahwa dengan mengetahui informasi tentang pilihan gaya belajar masing-masing siswa akan membuat guru lebih sensitif terhadap perbedaan siswa dalam kelas. Guru tidak hanya fokus pada satu teknik mengajar tertentu saja, tapi dapat menggantinya dengan teknik lain agar semua siswa dapa memaksimakan proses penerimaan ilmu pengetahuan. 
Kemampuan penalaran berperan penting dalam kesuksesan belajar matematika salah satu adalah untuk mengembangkan keterampilan siswa dalam memecahkan masalah. Menurut Ross dalam (Afif, Suyitno, \& Wardono, 2016), salah satu tujuan terpenting dari pembelajaran matematika adalah mengajarkan kepada siapa tentang penalaran. Hasil distribusi nilai kemampuan penalaran matematis siswa kelas VII SMP Negeri 10 Kendari tersaji pada Tabel 4.

Tabel 4. Distribusi Kemampuan Penalaran Matematis Siswa

\begin{tabular}{|c|c|c|c|c|}
\hline No. & Interval & Frekuensi & Persentase $(\%)$ & Kriteria \\
\hline 1 & $86-100$ & 2 & $1,51 \%$ & Sangat tinggi \\
\hline 2 & $76-85$ & 18 & $13,63 \%$ & Tinggi \\
\hline 3 & $66-75$ & 25 & $18,93 \%$ & Sedang \\
\hline 4 & $\leq 65$ & 87 & $65,90 \%$ & Rendah \\
\hline 5 & $0-15$ & 0 & $0 \%$ & Sangat Rendah \\
\hline
\end{tabular}

Hasil pada Tabel 4 menunjukkan bahwa persentase tertinggi kemampuan penalaran matematis siswa kelas VII SMP Negeri 10 kendari berada pada kategori rendah. Hal ini menandakan kemampuan penalaran matematis siswa pada sekolah tersebut mengalami kendala dan perlu upaya perbaikan oleh pihak sekolah dalam mendesain strategi pembelajaran yang tepat.

Hasil analisis inferensial terkait uji prasyarat menunjukkan data gaya belajar (visual, auditori, dan kinestetik) dan kemampuan penalaran matematis siswa berdistribusi normal dan uji linearitas juga menunjukkan bahwa gaya belajar (visual, auditori, dan kinestetik) dan kemampuan penalaran matematis memiliki hubungan yang linear. Selanjutnya, analisis regresi linear sederhana dimaksudkan untuk mengetahui pengaruh gaya belajar terhadap kemampuan penalaran matematis siswa tersaji pada Tabel 5.

Tabel 5. Analisis Regresi Linear Sederhana

\begin{tabular}{ccc}
\hline \multirow{2}{*}{ Gaya Belajar } & \multicolumn{2}{c}{ Unstandardized Coefficients } \\
\cline { 2 - 3 } & Coef. di B & Std. Error \\
\cline { 2 - 3 } & $-14,932$ & 20,792 \\
\cline { 2 - 3 } Visual & 0,938 & 0,254 \\
\hline Auditorial & $-8,770$ & 30,295 \\
\cline { 2 - 3 } & 0,852 & 0,372 \\
\hline Kinestetik & 2,894 & 23,396 \\
\cline { 2 - 3 } & 0,661 & 0,301 \\
\hline Gaya Belajar Keseluruhan & 26,374 & 0,183 \\
\hline
\end{tabular}

Berdasarkan hasil uji regresi pada Tabel 5 diperoleh beberapa persamaan regresi: (1) gaya belajar visual dengan kemampuan penalaran matematis yaitu $\widehat{Y}=-14,932+0,938(X)$ yang berarti bahwa dari fungsi taksiran regresi tersebut terlihat bahwa nilai konstanta $-14,932$ merupakan nilai kemampuan penalaran matematis tanpa ditunjang oleh gaya belajar visual siswa. Sedangkan koefisien arah regresi X sebesar 0,938 menunjukkan gaya belajar visual siswa berpengaruh positif terhadap kemampuan penalaran matematis. Dengan demikian, dapat dijelaskan bahwa jika variabel gaya belajar visual meningkat, maka akan diikuti dengan meningkatnya kemampuan penalaran matematis siswa; (2) gaya belajar auditorial dengan kemampuan penalaran matematis yaitu $\widehat{Y}=$ $8,770+0,852(X)$ yang berarti bahwa dari fungsi taksiran regresi tersebut terlihat bahwa nilai konstanta $-8,770$ merupakan nilai kemampuan penalaran matematis tanpa ditunjang oleh gaya belajar auditorial siswa. Sedangkan koefisien arah regresi X sebesar 0,852 menunjukkan gaya belajar auditorial siswa berpengaruh positif terhadap kemampuan penalaran matematis. Dengan demikian, dapat dijelaskan bahwa jika variabel gaya belajar auditorial meningkat, maka akan diikuti dengan meningkatnya kemampuan penalaran matematis siswa; (3) gaya belajar kinestetik dengan kemampuan penalaran matematis yaitu $\widehat{Y}=2,894+0,661(X)$ yang berarti bahwa dari fungsi taksiran regresi tersebut terlihat bahwa nilai konstanta 2,894 merupakan nilai kemampuan penalaran matematis tanpa ditunjang oleh gaya belajar kinestetik siswa. Sedangkan koefisien arah regresi $\mathrm{X}$ 
sebesar 0,661 menunjukkan gaya belajar kinestetik siswa berpengaruh positif terhadap kemampuan penalaran matematis. Dengan demikian, dapat dijelaskan bahwa jika variabel gaya belajar kinestetik meningkat, maka akan diikuti dengan meningkatnya kemampuan penalaran matematis siswa; (4) gaya belajar keseluruhan dengan kemampuan penalaran matematis yaitu $\widehat{Y}=26,374+0,386(X)$ yang berarti bahwa Dari fungsi taksiran regresi tersebut terlihat bahwa nilai konstanta 26,374 merupakan nilai kemampuan penalaran matematis tanpa ditunjang oleh gaya belajar keseluruhan siswa. Sedangkan koefisien arah regresi $\mathrm{X}$ sebesar 0,386 menunjukkan gaya belajar keseluruhan siswa berpengaruh positif terhadap kemampuan penalaran matematis. Dengan demikian, dapat dijelaskan bahwa jika variabel gaya belajar keseluruhan meningkat, maka akan diikuti dengan meningkatnya kemampuan penalaran matematis siswa. Untuk pengujian hipotesis uji regresinya tersaji pada Tabel 6 .

Tabel 6. Taraf Signifikansi dari Regresi

\begin{tabular}{lll}
\hline \multicolumn{1}{c}{ Gaya Belajar } & \multicolumn{1}{c}{ F } & Sig. \\
\hline Visual & 13,616 & 0.00 \\
\hline Auditorial & 5,259 & 0,03 \\
\hline Kinestetik & 4,837 & 0,04 \\
\hline Keseluruhan & 4,444 & 0,04 \\
\hline
\end{tabular}

Berdasarkan Tabel 6 diperoleh beberapa hasil uji regresi diantaranya: (1) uji koefisien regresi pada data gaya belajar visual dengan kemampuan penalaran matematis, diperoleh nilai signifikansi sebesar 0,000 lebih kecil dari $\alpha=0,05$ sehingga dapat disimpulkan bahwa gaya belajar visual mempunyai pengaruh yang signifikan terhadap kemampuan penalaran matematis siswa kelas VII SMP Negeri 10 Kendari; (2) uji koefisien regresi pada data gaya belajar visual dengan kemampuan penalaran matematis, diperoleh nilai signifikansi sebesar 0,03 lebih kecil dari $\alpha=0,05$ sehingga dapat disimpulkan bahwa gaya belajar auditorial mempunyai pengaruh yang signifikan terhadap kemampuan penalaran matematis siswa kelas VII SMP Negeri 10 Kendari; (3) uji koefisien regresi pada data gaya belajar visual dengan kemampuan penalaran matematis, diperoleh nilai signifikansi sebesar 0,04 lebih kecil dari $\alpha=0,05$ sehingga dapat disimpulkan bahwa gaya belajar kinestetik mempunyai pengaruh yang signifikan terhadap kemampuan penalaran matematis siswa kelas VII SMP Negeri 10 Kendari; (4) uji koefisien regresi pada data gaya belajar keseluruhan dengan kemampuan penalaran matematis, diperoleh nilai signifikansi sebesar 0,04 lebih kecil dari $\alpha=0,05$, sehingga dapat disimpulkan bahwa gaya belajar keseluruhan mempunyai pengaruh yang signifikan terhadap kemampuan penalaran matematis siswa kelas VII SMP Negeri 10 Kendari.

Koefisien determinasi menunjukkan seberapa bagus model regresi yang dibentuk oleh interaksi variabel gaya belajar dan kemampuan penalaran matematis siswa yang tersaji pada Tabel 7 .

Tabel 7. Koefisien Determinasi

\begin{tabular}{lc}
\hline \multicolumn{1}{c}{ Gaya Belajar } & F \\
\hline Visual & 0,188 \\
\hline Auditorial & 0,131 \\
\hline Kinestetik & 0,131 \\
\hline Keseluruhan & 0,033 \\
\hline
\end{tabular}

Berdasarkan Tabel 7 diperoleh hasil bahwa (1) gaya belajar visual memiliki pengaruh kontribusi sebesar 18,8\% terhadap kemampuan penalaran matematis siswa sedangkan sisanya 81,2\% dipengaruhi oleh faktor-faktor lain yang tidak diteliti dalam penelitian ini., (2) gaya belajar auditorial memiliki pengaruh kontribusi $13,1 \%$ terhadap kemampuan penalaran matematis siswa sedangkan sisanya $86,9 \%$ dipengaruhi oleh faktor-faktor lain yang tidak diteliti dalam penelitian ini.; (3) gaya belajar kinestetik memiliki pengaruh kontribusi $13,1 \%$ terhadap kemampuan penalaran matematis siswa sedangkan sisanya $86,9 \%$ dipengaruhi oleh faktor-faktor lain yang tidak diteliti dalam penelitian ini; (4) gaya belajar keseluruhan memiliki pengaruh kontribusi 3,3\% terhadap kemampuan penalaran matematis siswa sedangkan sisanya $96,7 \%$ dipengaruhi oleh faktor-faktor lain yang tidak diteliti dalam penelitian ini. 


\section{KESIMPULAN DAN SARAN.}

Berdasarkan hasil analisis dan pembahasan data diperoleh beberapa kesimpulan sebagai berikut: (1) gaya belajar siswa kelas VII SMP Negeri 10 Kendari yaitu gaya belajar visual sebanyak 61 siswa atau 46,21\%, gaya belajar auditorial sebanyak 37 siswa atau 28,03\%, dan gaya belajar kinestetik sebanyak 34 siswa atau $25,76 \%$; (2) kemampuan penalaran matematis siswa menunjukkan bahwa kategori sangat tinggi mencapai $1,51 \%$ atau sebanyak 2 siswa, kategori tinggi mencapai 13,63\% atau sebanyak 18 siswa, kategori sedang mencapai 18,93\% atau sebanyak 25 siswa, kategori kurang mencapai 65,90\% atau sebanyak 87 siswa dan kategori sangat kurang tidak ada; (3) gaya belajar siswa mempunyai pengaruh yang signifikan terhadap kemampuan penalaran matematis siswa kelas VII SMP Negeri 10 Kendari. Berdasarkan hasil penelitian yang dilakukan, maka saran yang dapat dikemukakan adalah sebagai berikut: (1) mengembangkan kemampuan matematika dan melatih siswa konsentrasi terhadap pembelajaran dengan menggunakan gaya belajar siswa, (2) siswa dapat sering berlatih untuk menyelesaikan soal-soal penalaran matematis, agar bagi siswa tersebut menjadi hal yang biasa bukan lagi hal yang sulit, serta menumbuhkan sifat percaya diri dalam setiap mengerjakan latihan-latihan soal penalaran matematis agar menumbuhkan inteligensi siswa tersebut.

\section{DAFTAR PUSTAKA}

Afiatman, N.H., Samparadja, H., \& Anggo, M. 2019. Pengaruh Kecemasan Matematika Terhadap Hasil Belajar Matematis Ditinjau Dari Gaya Belajar Siswa Kelas VIII SMP Negeri 4 Kendari. Jurnal Penelitian Pendidikan Matematika, 7 (3), 1-14.

Afif, A. M. S., Suyitno, H., \& Wardono, W. 2017. Analisis Kemampuan Penalaran Matematis Ditinjau dari Gaya Belajar Siswa dalam Problem Based Learning (PBL). PRISMA, Prosiding Seminar Nasional Matematika, 328-336.

Alifin, R., Kodirun, Ikman. 2018. Analisis Kemampuan Penalaran Matematis Siswa Kelas VIII SMP Negeri 5 Kendari Ditinjau Dari Perspektif Gender. Jurnal Penelitian Pendidikan Matematika, 6 (1), 155-168.

Ardianto, S., Sudia, M., \& Misu, L. 2016. Pengaruh Model Pembelajaran Berbasis Masalah Terhadap Kemampuan Penalaran Matematis Siswa Kelas VIII SMP Negeri 4 Kendari. Jurnal Pendidikan Matematika, 4 (1), 114-154.

Fauzan, \& Fahinu. 2016. Efektivitas Media Hands-On Equations Terhadap Kemampuan Penalaran Aljabar Siswa-Siswa Kelas VII SMP Negeri 2 Kendari. Jurnal Pendidikan Matematika, 4 (1), 43-56.

Hamidah, K.N. 2016. Profil Penalaran Matematika Siswa SMP Ditinjau Dari Gaya Belajar Kolb. Jurnal Ilmiah Pendidikan Matematika, 3 (5), 210-219

Haryono, A., \& Tanujaya, B. 2018. Profil Kemampuan Penalaran Induktif Matematika Mahasiswa Pendidikan Matematika Unipa Ditinjau Dari Gaya Belajar. Journal Of Honai Math, 1 (2), 127 138.

Hasibuan, E. K. 2018. Analisis Kesulitan Belajar Matematika Siswa Pada Pokok Bahasan Bangun Ruang Sisi Datar Di SMP Negeri 12 Bandung. AXIOM : Jurnal Pendidikan dan Matematika, 7 (1), 18-30.

Jafre, M., Abidin, Z., Rezaee, A.A., Abdullah, H.N., Kaur, K., \& Singh, B. 2011. Learning Styles and Overall Academic Achievement in a Specific Educational System. International Journal of Humanities and Social Science, 1(10), 143-152.

Jamilun, \& Suhar. 2016. Pengaruh Penerapan Model Pembelajaran Berbasis Masalah Terhadap Kemampua Penalaran Matematis Siswa Kelas VIII SMP Negeri 1 Kontukowuna. Jurnal Pendidikan Matematika, 4 (2), 99-112.

Linola, D. M., Marsitin, R., \& Wulandari, T. C. 2017. Analisis Kemampuan Penalaran Matematis Peserta Didik dalam Menyelesaikan Soal Cerita di SMAN 6 Malang. Pi: Mathematics Education Journal, 1 (1), 27-33.

Nisa, A.K., \& Ismail. 2018. Penerapan Model Pembelajaran Discovery Learning dengan Pendekatan Aptitude Treatment Interaction Pada Materi Menentukan Luas Permukaan Tabung dan Bola Kelas IX SMP. Mathedenusa: Jurnal Ilmiah Pendidikan Matematika, 1 (6), 8-15. 
Nurhayati, E., \& Subekti, F.E. 2017. Deskripsi Kemampuan Penalaran Matematis Siswa Ditinjau dari Gaya Belajar dan Gender. AlphaMath : Journal Mathematics Education, 3 (1), 66-78.

Pashler, H., M. McDaniel, D. Rohrer, \& R. Bjork. 2009. Learning Styles: Concepts and Evidence. A Journal of The Association for Psychological Science, 9 (3), 105-119.

Ridwan, M. 2017. Profil Kemampuan Penalaran Matematis Siswa ditinjau Dari Gaya Belajar. KALAMATIKA Jurnal Pendidikan Matematika, 2 (2), 193-206.

Sari, A.K. 2014. Analisis Karakteristik Gaya Belajar VAK(Visual, Auditorial, Kinestetik)Mahasiswa Pendidikan Informatika Angkatan 2014. Jurnal Ilmiah Edutic, 1 (1), 112.

Sari, I. P., \& Sufri, (2014). Analisis Penalaran Proporsional Siswadengan Gaya Belajar Auditori Dalam Menyelesaikan Soal Perbandinganpada Siswa Smp Kelas VII. Edumatica, 4 (2), 48-55.

Syarfuni \& Verawati. 2017. Analisis Karakteristik Gaya Belajar Mahasiswa Pendidikan Bahasa Inggris Angkatan 2016 STKIP Bina Bangsa Getsempena Banda Aceh, Genta Mulia: Jurnal Ilmiah Pendidikan, 8 (1), 75-83

Syukur. M., \& Misu, L. 2016. Hubungan Antara Gaya Belajar Dengan Hasil Belajar Matematika Siswa Kelas XI SMAN 4 Kendari. Jurnal Penelitian Pendidikan Matematika, 4 (2), 153-166.

Waskitoningtyas, R. S. 2016. Analisis Kesulitan Belajar Matematika Siswa Kelas V Sekolah Dasar Kota Balikpapan Pada Materi Satuan Waktu Tahun Ajaran 2015/2016. JIPM (Jurnal Ilmiah Pendidikan Matematika), 5 (1), 24-32.

Zariah, A., Kodirun \& Masi, L. 2019. Pengaruh Gaya Belajar Terhadap Pengetahuan Dasar Matematika Siswa Smp Negeri 8 Kendari. Jurnal Penelitian Pendidikan Matematika, 7 (2), 1528. 